\title{
Corrosion Behavior of 316L and Alloy 182 Dissimilar Weld Joint with Post-Weld Heat Treatment
}

\author{
João Henrique Nery Garcia ${ }^{1}$, Neice Ferreira dos Santos ${ }^{1}$, \\ Luiza Esteves ${ }^{1}$, Wagner Reis da Costa Campos ${ }^{1}$, \\ Emerson Giovani Rabelo ${ }^{1}$
}

\footnotetext{
${ }^{1}$ Centro de Desenvolvimento da Tecnologia Nuclear - CDTN, Belo Horizonte, Minas Gerais, Brasil. e-mail: jhnery11@gmail.com, neice_ferreira@hotmail.com, luizaeq@yahoo.com.br,wrcc@cdtn.br, egr@cdtn.br
}

\begin{abstract}
Austenitic stainless steel and nickel-base alloys welds are widely used in nuclear reactor components, plants of energy generation, chemical, and petrochemical industries, due to their high corrosion resistance. The post weld heat treatments (PWHT) are generally applied to welding in order to relieve the welding residual stress. The aim of this work was to evaluate the influence of different PWHT on corrosion behavior of a dissimilar weld joint of two AISI 316L austenitic stainless steel plates with a nickel-base alloy as filler material in saline environments. The material was submitted to heat treatments for three hours at 600,700 and $800{ }^{\circ} \mathrm{C}$. The weld joint was examined by optical microscopy to determine the effects of PWHT in the microstructure. The corrosion behavior of the samples before and after heat treatment was evaluated using cyclic potentiodynamic polarization (CPP) in sodium chloride solutions (19\% v/v) and pH 4.0 at room temperature. Metallographic analyses showed that delta ferrite dissolute as PWHT temperature increased. CPP curves demonstrated an increase of pitting corrosion resistance as the PWHT temperature rises, although the pit size has been increased. The heat treated weld joint at $600{ }^{\circ} \mathrm{C}$ showed a similar corrosion resistance compared to as-welded material.
\end{abstract}

Keywords: weld joint, post-weld treatment, polarization, pitting corrosion.

\section{INTRODUCTION}

Dissimilar metal welds (DMWs) or bimetallic welds refer to welds between two different metals [1]. Austenitic stainless steel and nickel-base alloys are generally used in DMWs, and such alloys are employed in nuclear reactor components, plants of energy generation, chemical, and petrochemical industries due to their high corrosion resistance [2-7]. The welds in nuclear power plants are employed in high temperature operating components [7]. For plant safety it is essential to keep the structural integrity of these DMWs during service life [1].

Austenitic stainless steel and nickel-base alloys may require a post weld heat treatment (PWHT) in order to remove the welding residual stress and the PWHT is generally applied to the weldment [8-10]. Residual stresses can be significantly reduced by PWHT in austenitic materials at a temperature range from 480 to $925{ }^{\circ} \mathrm{C}$. At the higher end of this range, nearly $85 \%$ of the residual stresses may be relieved. However, PWHT at this range may result in sensitizing susceptible material, hence, these heat treatments should be only used for low carbon grades "L" and the 321 and 347 stabilized steels $[1,5,8,11]$.

The mechanical properties and corrosion resistance of welded joints can be affected by the welding process and PWHT resulting in microstructural variations such as carbide precipitation and sigma phase [1219]. The dissolution of ferrite occurs as heat treatment temperature increases above $500{ }^{\circ} \mathrm{C}$ in stainless steel. During its dissolution, part of delta ferrite is transformed into austenite plus carbides and second phases. The main intermetallic, in austenitic stainless steel AISI 316 or $316 \mathrm{~L}$, is sigma constituted with higher levels of carbon, chromium and molybdenum, and lower levels of nickel and iron [2,9,10,20-22].

The corrosion behavior of the metals and alloys depends on the transformation of the microstructure and the chemical composition caused by the weld thermal history that occurs during the welding process. Hence, the corrosion resistance of weld may be inferior to the resistance of base metal, due to precipitation, microsegregation, the formation of unmixed zones, contamination of the solidifying weld pool, secondary phase and recrystallization and grain growth in the weld heat-affected zone (HAZ) [23,24]. The corrosion resistance can be preserved in the welded condition by balancing alloy compositions to avoid undesirable 
precipitation reactions, by selecting the proper welding parameters, by shielding molten hot metal surfaces from reactive gases in the weld environment, by extracting chromium-enriched oxides, and chromiumdepleted base metal from thermally discolored surfaces [25-27].

In this work, the influence of different PWHT on corrosion behavior of a dissimilar welds involving AISI 316L stainless steel and nickel-base alloy 182 was investigated using the electrochemical technique: cyclic potentiodynamic polarization (CPP) in sodium chloride solutions (19\%v/v) and pH 4.0 at room temperature.

\section{MATERIALS AND METHODS}

\subsection{Materials and welding procedure}

The base metal (BM) used for welding in the present investigation was an austenitic stainless steel AISI 316L plates with $300 \mathrm{~mm}$ (length), $150 \mathrm{~mm}$ (width), and $12.7 \mathrm{~mm}$ (thickness). The filler metal was nickel-base alloy 182 with diameters of 2.5 and $3.2 \mathrm{~mm}$. The nominal chemical composition of the base and the filler metal are shown in Table 1. The plates of stainless steel AISI 316L were prepared for the weld employing a single $\mathrm{V}$ groove edge preparation with an included angle of $30^{\circ}$. The top plates were welded with a narrow gap of $2.5 \mathrm{~mm}$, with pre-heating at $150{ }^{\circ} \mathrm{C}$, and interpass temperature between 100 to $150{ }^{\circ} \mathrm{C}$ by shielded metal arc welding (SMAW). The weld joint (WJ) was performed with $90-100 \mathrm{~A}$ for the root weld (filler metal of $2.5 \mathrm{~mm}$ ), and $110-120$ A for the other beads (filler metal of $3.2 \mathrm{~mm}$ ). In order to compensate the deformations due to the welding process a lift was designed in the central region of the weld, supported by a copper plate $300 \mathrm{~mm}$ x $50 \mathrm{~mm}$ x $10 \mathrm{~mm}$ as shown in Figure 1. After welding, a PWHT was performed at 600, 700 and $800{ }^{\circ} \mathrm{C}$ for 3 hours to relieve residual stresses of the welded joints. All samples were taken from similar places of the welds. The sampling location was the root welding.

Table 1: Nominal chemical composition of base metal (AISI 316L) and filler metal (Inconel® 182) (\% in weight).

\begin{tabular}{l|l|l|l|l|l|l|l|l|l|l|l|l|l}
\hline MATERIAL & CU & CO & CR & MO & FE & SI & MN & C & II & S & P & NB & NI \\
\hline AISI 316L & - & - & 16,000 & 2,000 & Bal. & 0,750 & 2,000 & 0.030 & - & 0,030 & 0,045 & - & 10,000 \\
\hline Inconel $^{\circledR} 182$ & 0,040 & 0,050 & 16,533 & - & 3,580 & 0,506 & 5,703 & 0,026 & 0,116 & 0,008 & 0,010 & 1,910 & Bal. \\
\hline
\end{tabular}

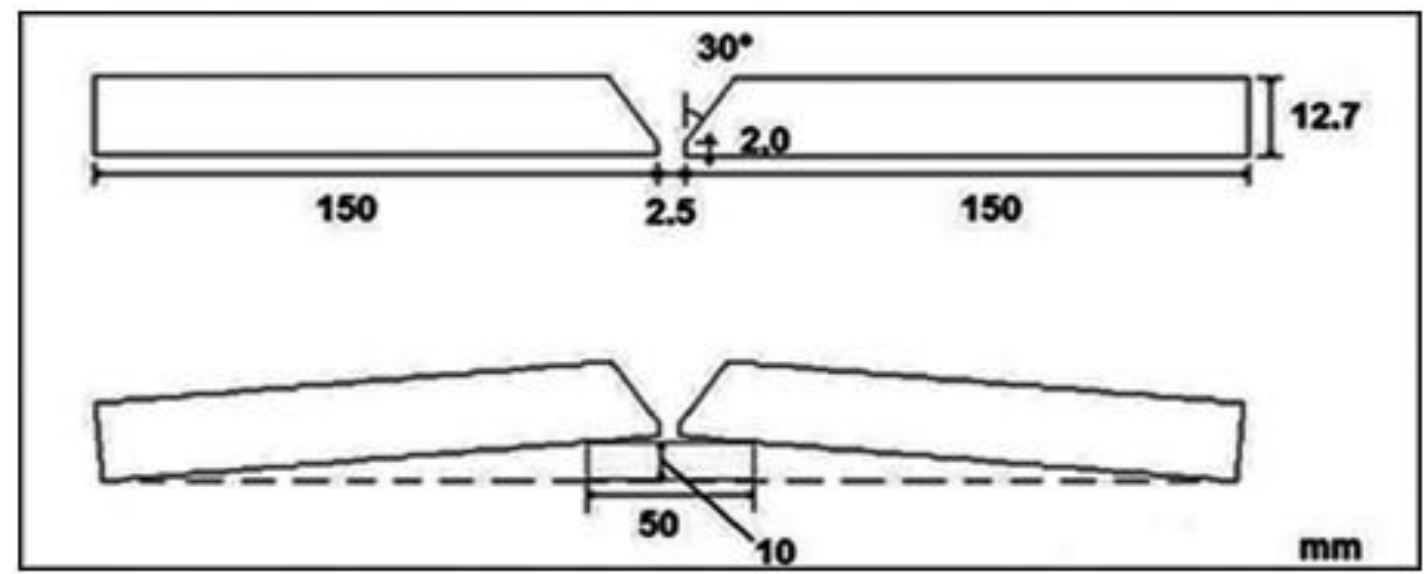

Figure 1: Scheme of the copper plate position prior to welding.

\subsection{Microstructure analysis}

The cross-section of the welded specimens were mechanically polished with $1 \mu \mathrm{m}$ and electrolytically etched in a $10 \%$ oxalic acid solution at $2.2 \mathrm{~V} \mathrm{DC}$ for $60 \mathrm{~s}$ in order to examine the microstructure and to identify grains, dendrite boundaries, and precipitates. The microstructures analyses were carried out by an optical microscope.

\subsection{Eletrochemical measurements}

The specimens for electrochemical measurements were weld to a copper wire, and embedded in epoxy resin. 
The working surface was then abraded with SiC papers of grit size from 80 to 600 mesh and cleaned with distilled water and alcohol. The surface area of the samples was measured by Image $\mathrm{J}$ software. The average size of sample area was about $2.0 \mathrm{~cm}^{2}$.

Electrochemical measurements were performed using an Autolab PGSTAT 20 potentiostat and an electrochemical cell of three electrodes: base metal and the welded samples as working electrode, platinum mesh as counter electrode and silver chloride electrode $(\mathrm{Ag} / \mathrm{AgCl}, 3 \mathrm{M} \mathrm{KCl})$ as reference electrode. The electrochemical tests were carried out at $25^{\circ} \mathrm{C}$ and $\mathrm{pH} 4.0$ containing $190 \mathrm{~g} / \mathrm{L} \mathrm{NaCl}$ and $0.4 \mathrm{~g} / \mathrm{L}$ sodium acetate ( $5 \mathrm{mM} \mathrm{CH} \mathrm{COONa}_{3} \mathrm{COO}$. The open circuit potential (OCP) was recorded for $1 \mathrm{~h}$ or until stabilization, and the $\mathrm{CPP}$ curves were collected by scanning to the anodic direction at a scan rate of $0.167 \mathrm{mV} \mathrm{s} \mathrm{s}^{-1},-0.02 \mathrm{~V}_{\mathrm{Ag} / \mathrm{AgCl}}$ from the stabilized OCP. When the current reached $1 \mathrm{~mA} / \mathrm{cm}^{2}$ the scan was reversed. All the electrochemical measurements were repeated at least three times to ensure the reproducibility. The pitting potential $\left(\mathrm{E}_{\mathrm{pit}}\right)$ was defined as the potential value at which the current density sharply rose. After the electrochemical tests, surface morphology was examined using an optical microscope and scanning electronic microscope (SEM).

\section{RESULTS AND DISCUSSION}

The microstructure of the base metal (AISI 316L) consists of austenite grains and stringers of delta ferrite, and the PWHT caused dissolution of delta ferrite as shown in Figure 2. The weld metal microstructure consists of dendrite grains, with inclusions and precipitates. The amount of precipitates in the weld metal decreased with an increase in temperature of the PWHT. The delta ferrite was partially dissolved in the HAZ with an increasing temperature of the PWHT. The delta ferrite content of the base and weld metals decreased with an increase in the annealing temperature [14,15]. It was measured for the base metal by image analyzing software for microstructure analyzing Quantikov, and shown in Table 2 [28]. 


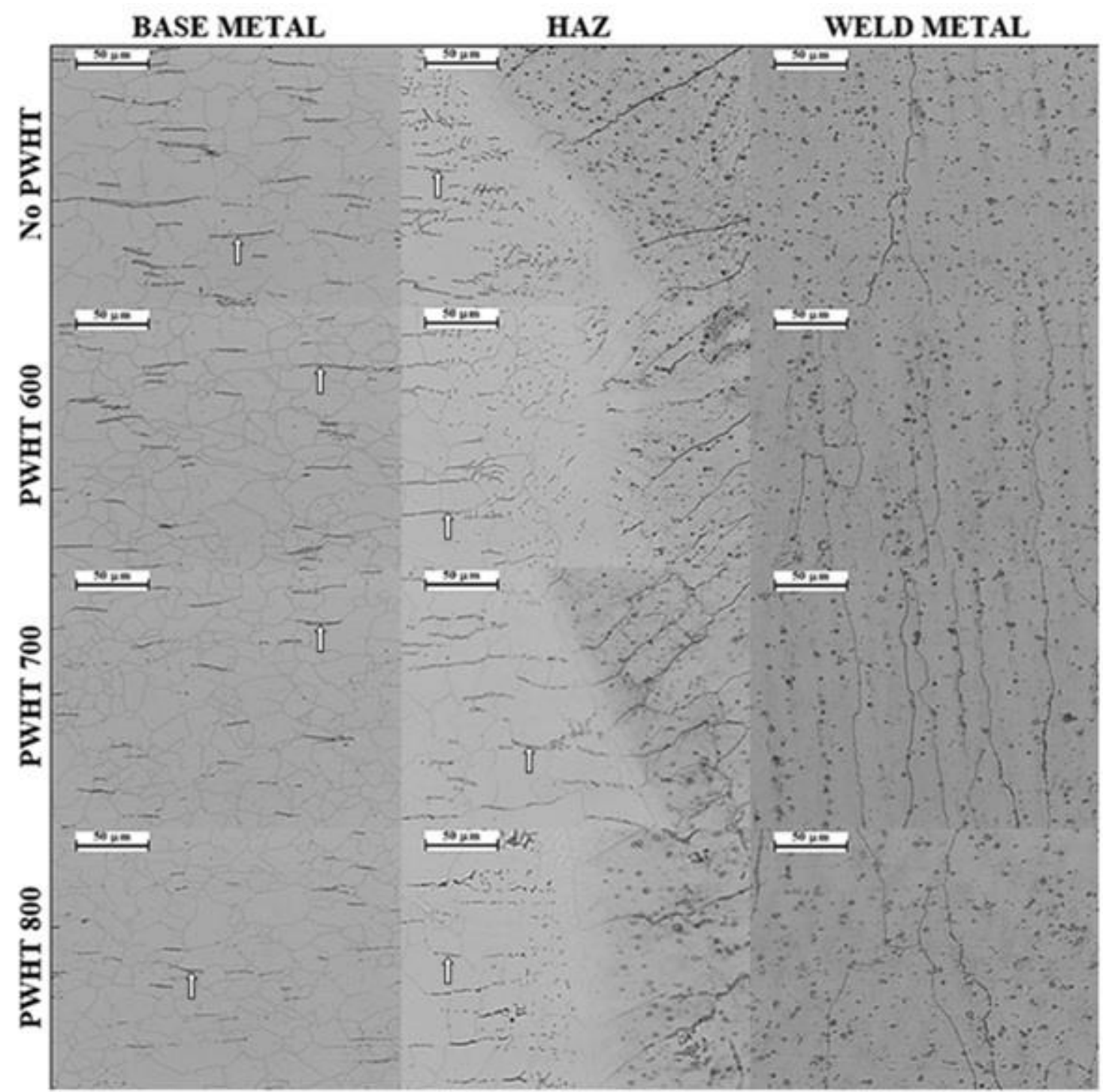

Figure 2: Micrographs of base metal, weld metal, and weld joint before and after PWHT. The arrows points to delta ferrite.

Table 2: Delta ferrite content measured by color analyzing software.

\begin{tabular}{ll}
\hline SAMPLE & DELTA FERRITE CONTENT (\%) \\
\hline No PWHT & $3,46 \pm 0,63$ \\
PWHT $600{ }^{\circ} \mathrm{C}$ & $2,32 \pm 0,44$ \\
PWHT $700{ }^{\circ} \mathrm{C}$ & $1,80 \pm 0,16$ \\
PWHT $800{ }^{\circ} \mathrm{C}$ & $1,58 \pm 0,20$ \\
\hline
\end{tabular}

The polarization curves for base metal and weld joints, before and after PWHT $\left(600-800{ }^{\circ} \mathrm{C}\right)$ in a $19 \%$ wt. $\mathrm{NaCl}$ solution ( $\mathrm{pH} 4.0$ ), are shown in Figure 3. According to literature, chloride-containing acidic environments lead to more severe pitting corrosion [29]. Table 3 contains the results of polarization studies, which comprises the corrosion potential $\left(\mathrm{E}_{\text {corr }}\right)$, passive current $\left(\mathrm{I}_{\text {pass }}\right)$, pitting potential $\left(\mathrm{E}_{\text {pit }}\right)$ and protection potential $\left(\mathrm{E}_{\text {prot }}\right)$. 

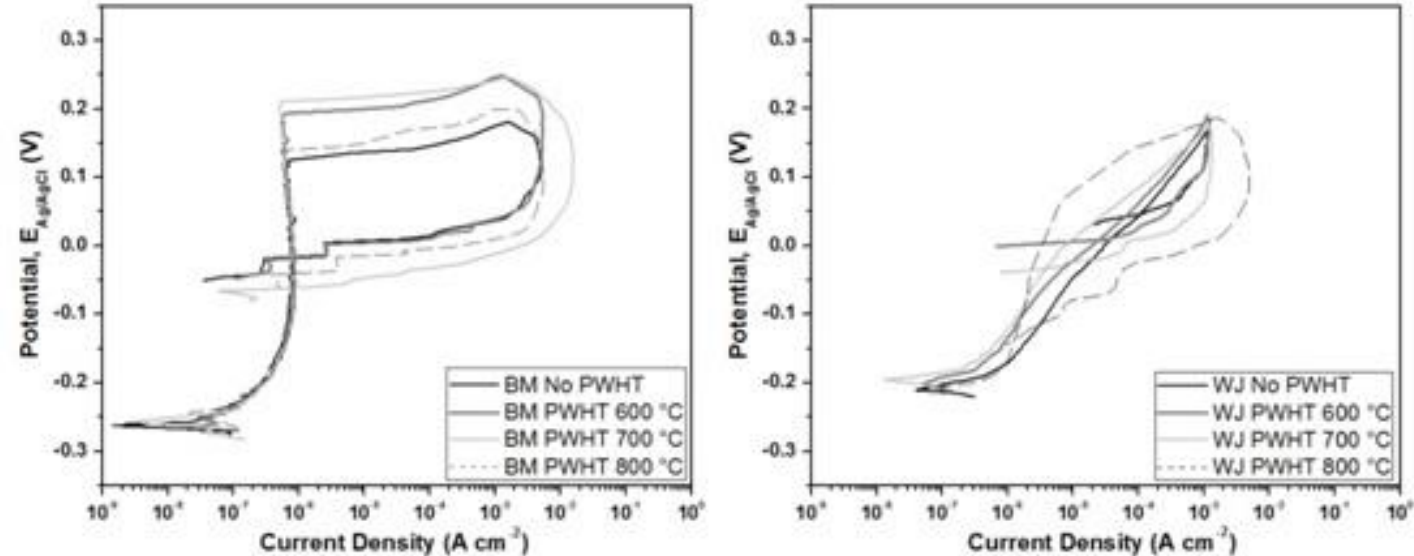

Figure 3: Polarization curves for base metal (left) and weld joints (right) as welded and after PWHT in $19 \%$ wt. NaCl solution

Table 3: Electrochemical parameters in solution containing $\mathrm{NaCl}$ concentration $19 \% \mathrm{wt}$

\begin{tabular}{|c|c|c|c|c|}
\hline SAMPLE & $\begin{array}{l}E_{\text {corr }} \\
\left(\mathrm{mV}_{\mathrm{Ag} / \mathrm{AgCl}}\right)\end{array}$ & $\begin{array}{l}\mathrm{I}_{\text {pass }} \\
\left(\mu \mathrm{A} \cdot \mathrm{cm}^{-2}\right)\end{array}$ & $\begin{array}{l}E_{\text {pit }} \\
\left(\mathrm{mV}_{\mathrm{Ag} / \mathrm{AgCl}}\right)\end{array}$ & $\begin{array}{l}E_{\text {prot }} \\
\left(\mathrm{mV}_{\mathrm{Ag} / \mathrm{AgCl}}\right)\end{array}$ \\
\hline WJ No PWHT & $-211,0 \pm 1,0$ & $3,0 \pm 1,3$ & $-43,0 \pm 15,1$ & $29,6 \pm 23,5$ \\
\hline WJ PWHT $600^{\circ} \mathrm{C}$ & $-217,5 \pm 21,9$ & $9,9 \pm 6,2$ & $-49,5 \pm 0,7$ & $8,9 \pm 0,4$ \\
\hline WJ PWHT $700{ }^{\circ} \mathrm{C}$ & $-197,0 \pm 9,0$ & $1,8 \pm 1,2$ & $-18,3 \pm 9,6$ & $-42,5 \pm 25,9$ \\
\hline WJ PWHT $800^{\circ} \mathrm{C}$ & $-217,0 \pm 30,0$ & $0,6 \pm 0,4$ & $43,0 \pm 11,7$ & $-112,9 \pm 32,0$ \\
\hline
\end{tabular}

All weld joints showed a passive behavior, although the specimen of PWHT at $800{ }^{\circ} \mathrm{C}$ clearly demonstrated a wider and more defined passive region. PWHT has no influence on $\mathrm{E}_{\text {corr }}$ value; this parameter was measured around $-200 \mathrm{mV}_{\mathrm{Ag} / \mathrm{AgCl}}$ for all the specimens. The weld joint heat treated at $600{ }^{\circ} \mathrm{C}$ has similar corrosion behavior compared to the as-welded joint. As the temperature of PWHT increased, $\mathrm{E}_{\text {pit }}$ also increased, and $E_{\text {prot }}$ decreased. This increase of $E_{p i t}$ can be explained by a higher dissolution of delta ferrite at higher temperatures, this phase has deleterious effects on corrosion resistance [4,30-35]. It is known that delta ferrite provides a favorable sites for pitting initiation [34]. Pitting potential and current density shift towards higher values, the passive region becomes wider for the base metal when compared with welded joints [36]. Therefore, the welded joint showed lower corrosion resistance than the base metal $[18,19,37]$ as summarized in Figure 4.

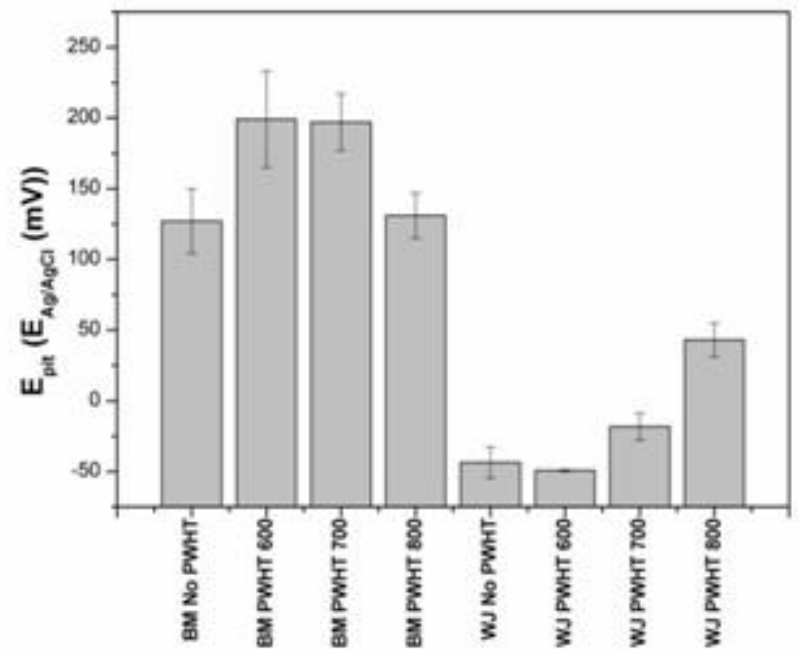

Figure 4: $\mathrm{E}_{\mathrm{pit}}$ for weld joints and base metal before and after PWHT. 
Metallographic examination of the weld joints after the cyclic potentiodynamic polarization revealed pitting corrosion as shown in Figure 5. The pit morphologies are roughly circular or elliptical and their diameter depends on PWHT temperature. Higher PWHT temperature has led to larger pits, showing a large hysteresis loop ( $\left.\mathrm{E}_{\mathrm{pit}}-\mathrm{E}_{\mathrm{prot}}\right)$ due to the difficulty to attain the passive layer. According to Chen et. al. [39], after the pit initiation, the pit may continue growing between the $\mathrm{E}_{\text {pit }}$ and $\mathrm{E}_{\text {prot }}[38,39]$. The majority pits were found near the fusion line in the weld metal, since the local properties of the fusion zone are often inferior to those of the base metal [19], which can be attributed to segregation during solidification [23,34]. It was observed that after PWHT the phosphorus and aluminum segregation decreased, and it is known that phosphorus segregation can enhance corrosion [40]. The overlapped regions are usually the weakest sites to resist the corrosion attack in the weld metal, due to their microstructure morphology differences which promote a galvanic attack [23].
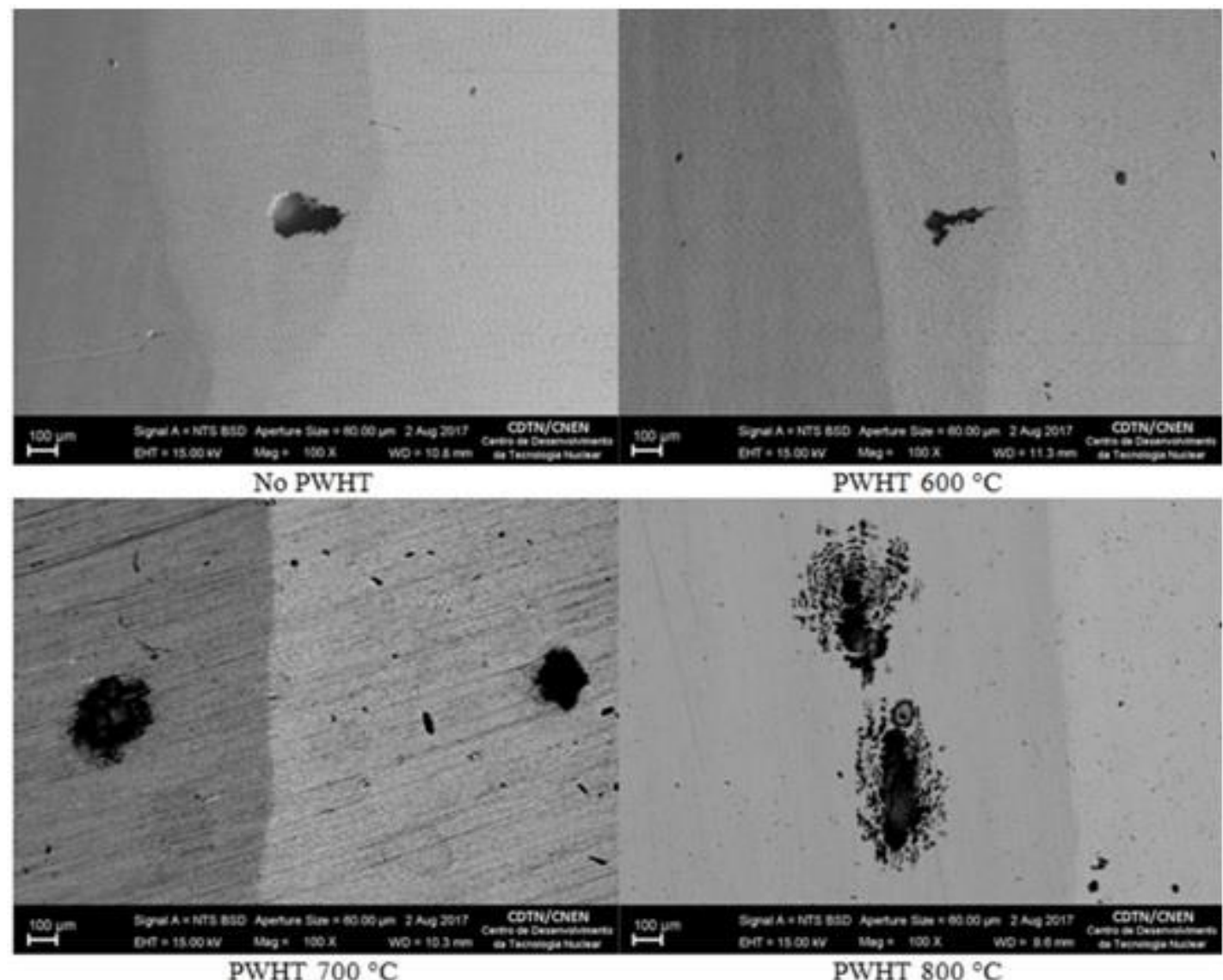

Figure 5: SEM micrographs of weld joints as welded and after PWHT after cyclic polarization.

\section{CONCLUSIONS}

Polarization curves showed that heat treatments at higher temperatures increase the weld joint tendency to passivate. The PWHT at $800{ }^{\circ} \mathrm{C}$ had a wider and more defined passive region and the highest pitting corrosion resistance. The PWHT at this temperature provided a better corrosion resistance to the weld joint. However, also presented the lowest protection potential, thus, once a pit is developed, it will grow to larger sizes until its repassivation. The pitting corrosion resistance increased with temperature due to higher dissolution of delta ferrite at higher temperatures. The corrosion resistance of the weld joints was lower than the base metal before and after PWHT.

\section{ACKNOWLEDGMENTS}

The authors are grateful to the Brazilian government agencies (CNPq, CNEN, CAPES, and FAPEMIG) for the financial support for this research and the Centro de Desenvolvimento da Tecnologia Nuclear - CDTN for the technical support. 


\section{BIBLIOGRAPHY}

[1] MITEVA, R. TAYLOR, N.G. General Review of Dissimilar Metal Welds in Piping Systems of Pressurised Water Reactors, Including WWER Designs, 1 ed., Petten, Netherlands, European Comission, 2006.

[2] NELSON, T.W., LIPPOLD, J.C., MILLS, M.J. "Nature and Evolution of the Fusion Boundary in FerriticAustenitic Dissimilar Metal Welds — Part 1 : Nucleation and Growth”, Welding Journal, pp.267s-277s, Oct. 1999.

[3] NELSON, T.W., LIPPOLD, J.C., MILLS, M.J. "Nature and Evolution of the Fusion Boundary in FerriticAustenitic Dissimilar Metal Welds — Part 2: On-Cooling Transformations”, Welding Journal, pp.267s277s. Oct. 2000.

[4] GILL, T.P.S., VIJAYALKSHMI, M., RODRIGUEZ, P., et al., "On microstructure-property correlation of thermally aged type 316L stainless steel weld metal”, Metallurgical Transactions A, v.20, n.6, pp.11151124, Jun. 1989

[5] ROWE, M.D., NELSON, T.W., LIPPOLD, J.C., "Hydrogen-Induced Cracking along the fusion boundary of dissimilar metal welds", Welding Journal, pp.31-37, Feb. 1999.

[6] GUPTA, K., CHHIBBER, R. "Structural Integrity of Bimetallic Welds At Elevated Temperature", International Journal of Mechanical Engineering Technology, v.3, n.1, pp.235-243, Apr. 2012.

[7] SARIKKA, T., AHONEN, M., MOUGINOT, R., et al. "Microstructural, mechanical, and fracture mechanical characterization of SA 508-Alloy 182 dissimilar metal weld in view of mismatch state", International Journal of Pressure Vessel and Piping, v.145, pp.13-22, Jun. 2016.

[8] TSAI, W.T., YU, C.L., LEE, J.I., "Effect of heat treatment on the sensitization of Alloy 182 weld", Scripta Materialia, v.53, p p.505-509, Jun. 2005.

[9] SMITH, J., FARRAR, R. "Influence of microstructure and composition on mechanical properties of some AISI 300 series weld metals", International Materials Reviews, v.38, n.1, pp.3-9, 1993.

[10] LO, I.H., TSAI, W.T., "Effect of heat treatment on the precipitation and pitting corrosion behavior of 347 SS weld overlay”, Materials Science Engineering A, v.355, pp.137-143, Jan. 2003.

[11] SIREESHA, M., VIJAYALKSHMI, M., RODRIGUEZ, P., el al. "A comparative evaluation of welding consumables for dissimilar welds between 316LN austenitic stainless steel and alloy 800", Journal of Nuclear Materials, v.279, pp.65-76, Nov. 1999.

[12] SIREESHA, M., ALBERT, S.K., SUNDARESAN, S., "Metallurgical changes and mechanical behaviour during high temperature aging of welds between Alloy 800 and 316LN austenitic stainless steel", Materials Science and Technology, v.19, pp.1411-1417, Oct. 2003.

[13] MUDALI, U.K., DAYAL, R.K. "Fitting corrosion resistance of as welded and thermally aged nitrogen containing type 316 stainless steel weld metal”, Materials Science and Technology, v.16, pp.393-398, Apr. 2000.

[14] PADILHA, A.F. RIOS, P.R. "Decomposition of Austenite in Austenitic Stainless Steels", ISIJ International, v.42, n.4, pp.325-327, Jan. 2002.

[15] KOŽUH, S., GOJI, M. "Mechanical properties and microstructure of austenitic stainless steel after welding and post-weld heat treatment", Kovove Materiarly, v.47, pp.253-262, Feb. 2009.

[16] MUHAMMAD, F., AHMAD, A., FAROOQ, A., et al., "Effect of Post-Weld Heat Treatment on Mechanical and Electrochemical Properties of Gas Metal Arc-Welded 316L (X2CrNiMo 17-13-2) Stainless Steel”, Journal of Materials Engineering and Performance, v.25, n.10, pp.4283-4291, Oct. 2016.

[17] PUJAR, M.G., DAYAL, R.K., GILL, T.P.S., et al., "Evaluation of Microstructure and Electrochemical Corrosion Behavior of Austenitic 316 Stainless Steel Weld Metals with Varying Chemical Compositions", Journal of Materials Engineering and Performance, v.14, n.3, pp.327-342, Jun. 2005.

[18] GARCIA, C., MARTIN, F., TIEDRA, P., et al., "Pitting corrosion of welded joints of austenitic stainless steels studied by using an electrochemical minicell", Corrosion Science, v.50, n.4, pp.1184-1194, Jan. 2008.

[19] REDDY, G.M., GOKHALE, A.A., NARENDRA, N., et al., "Influence of welding techniques on microstructure and pitting corrosion behaviour of 1441 grade Al-Li alloy gas tungsten arc welds", British Corrosion Journal, v.36. n.4, pp.304-309, Jul. 2001.

[20] SOARES, B.A., SCHVARTZMAN, M. M. A. M., CAMPOS, W. R. C., "Characterization of the Dissimilar Welding - Austenitic Stainless Steel With Filler Metal of the Nickel Alloy”, In: 2007 International Nuclear Atlantic Conferecence - INAC 2007, Santos, São Paulo, Brasil, Oct, 2007. 
[21] KOŽUH, S., GOJIĆ, M., KOSEC, L., "The effect of annealing on properties of AISI 316L base and weld metals", Materials and Geoenvironment, v.54, n.3, pp.331-344, Dec. 2007.

[22] SCHWIND, M., KÄLLQVIST, J., NILSSON, J.O., et al., "Sigma-Phase Precipitation in Stabilized Austenitic Stainless Steels", Acta Materialia, v.48, pp.2473-2481, Mar. 2000.

[23] CUI, Y. LUNDIN, C.D. "Evaluation of initial corrosion location in E316L austenitic stainless steel weld metals", Materials Letter, v.59, pp.1542-1546, Feb. 2005.

[24] LU, B.T., CHEN, Z.K., LUO, J.L., et al., "Pitting and stress corrosion cracking behavior in welded austenitic stainless steel", Electrochimica Acta, v.50, n.6, pp.1391-1403, Jan. 2005.

[25] WAHID, A. OLSON, D. L. MATLOCK, D. K.. Corrosion of Weldments, ASM Handbook, Welding, Brazing and Soldering, v. 6. ASM International. 1993.

[26] DADFAR, M., FATHI, M.H., KARIMZADEH, F., et al., "Effect of TIG welding on corrosion behavior of 316L stainless steel", Materials Letters, v.61, pp.2343-2346, Sep. 2006.

[27] TIMOFEEV, B.T., et al., "Corrosion and mechanical strength of welded joints of downcomers for RBMK reactors", International Journal of Pressure Vessel and Piping, v.76, pp.299-307, Nov. 1998.

[28] PINTO, L. C. M. "Quantikov: Um analisador microestrutural para o ambiente Windows", Tese de D. Sc., Universidade de São Paulo - USP, São Paulo, SP, Brasil, 1996.

[29] JIN, Z.H., GE, H.H., LIN, W.W., et al., "Corrosion behaviour of 316L stainless steel and anti-corrosion materials in a high acidified chloride solution", Applied Surface Science, v.322, pp.47-56, Oct. 2014.

[30] KOŽUH, S., GOJIC, M., ROKOVIC, M.K. "The Effect of PWHT on Electrochemical Behaviour of AISI 316L Weld Metal", Chemical and Biochemical Engineering Quaterly, v.22, n.4, pp.421-431, Sep. 2008.

[31] FARID, M. MOLIAN, P.A. "High-brightness laser welding of thin-sheet 316 stainless steel", Journal of Materials Science, v.35, n.15, pp.3817-3826, 2000.

[32] ZUMELZU, E. SEPÚLVEDA, J., IBARRA, M. "Influence of microstructure on the mechanical behaviour of welded 316 L SS joints", Journal of Materials Processing Technology, v.94, n.1, pp.36-40, Jan. 1998.

[33] PUJAR, M.G., DAYAL, R.K., GILL, T.P.S., et al., "Role of delta-ferrite in the dissolution of passive films on the austenitic stainless-steel weld metals", Journal of Materials Science Letter, v.18, n.10, pp.823826, Nov. 1998.

[34] CUI, Y., LUNDIN, C.D. "Austenite-preferential corrosion attack in 316 austenitic stainless steel weld metals", Materials and Design, v.28, n.1, pp.324-328, Aug. 2005.

[35] GILL, T.P.S., GNANAMOORTHY, J.B., PADMANABHAN, K.A. "Influence of Secondary Phases on the Localized Corrosion of Thermally Aged Aisi 316L Stainless Steel Weld Metal", Corrosion, v.43, n.4, pp.208-213, Apr. 1987.

[36] CUI, L., XIAOGANG, L., CHAOFANG, D. "Pitting and galvanic corrosion behavior of stainless steel with weld in wet-dry environment containing Cl-“, Journal of University of Science and Technology Beijing: Mineral Metallurgy Materials (England Edition), v.14, n.6, pp.517-522, Dec. 2007.

[37] BLASCO-TAMARIT, E., et al., "Effect of aqueous $\mathrm{LiBr}$ solutions on the corrosion resistance and galvanic corrosion of an austenitic stainless steel in its welded and non-welded condition", Corrosion Science, v.48, n.4, pp.863-886, Apr. 2006.

[38] WILDE, B.E. "Critical Appraisal of Some Popular Laboratory Electrochemical Tests for Predicting the Localized Corrosion Resistance of Stainless Alloys in Sea Water", Corrosion, v.28, n.8, pp.283-291, Aug. 1972.

[39] CHEN, Y.Y., CHOU, L.B., SHIH, H.C. "Effect of solution $\mathrm{pH}$ on the electrochemical polarization and stress corrosion cracking of Alloy 690 in $5 \mathrm{M} \mathrm{NaCl}$ at room temperature", Materials Science Engineering A., v.396, n.2, pp.129-137, Jan. 2005.

[40] BRIANT, C.L., TOOLE, C.S.O., HALL, E.L. "The Effect of Microstructure on the Corrosion and Stress Corrosion Cracking of AIIoy 600 in Acidic and Neutral Environments", Corrosion, v.42, n.1, pp.15-27, Jan. 1986.

\section{ORCID}

João Henrique Nery Garcia Luiza Esteves https://orcid.org/0000-0002-6944-3219

https://orcid.org/0000-0003-3998-664X 
Neice Ferreira dos Santos

Emerson Giovani Rabelo

Wagner Reis da Costa Campos https://orcid.org/0000-0003-2906-2339

https://orcid.org/0000-0001-9391-0676

https://orcid.org/0000-0001-6157-3791 